\title{
48,XXXY syndrome
}

INSERM

\section{Source}

INSERM. (1999). Orphanet: an online rare disease and orphan drug data base. $\underline{48, X X X Y}$ syndrome. ORPHA:96263

The 48,XXXY syndrome represents a chromosomal anomaly of the aneuploidic type characterized by the presence of two extra $X$ chromosomes in males. 